\title{
A MÃE NATUREZA E O PATER POTESTAS: BREVES CONSIDERAÇÕES SOBRE PENTESILEIA, DE HEINRICH VON KLEIST ${ }^{1}$
}

João Guilherme Dayrell Doutorando em Literatura Comparada do Programa de Pós-graduação em Estudos Literários /

\begin{abstract}
RESUMO
Este artigo analisa a tragédia Pentesileia, de Heinrich von Kleist, a partir da teorias acerca do matriarcado desenvolvidas por Johan Jakob Bachofen e seus desdobramentos na tradição germânica, quais sejam: Nietzsche, Engels e Freud. Atenta-se, entre outros, a suposta separação entre homem e natureza/animalidade.
\end{abstract}

\section{PALAVRAS-CHAVE}

Pentesileia, Kleist, Bachofen, matriarcado

\footnotetext{
${ }^{1}$ Agradeço imensamente ao amigo Alexandre Nodari, que, muito gentilmente, cedeu-me os áudios das aulas oferecidas por ele em parceria com o antropólogo Eduardo Viveiros de Castro, sem dúvida, um dos maiores pensadores da atualidade. O curso foi ministrado por ambos no Museu Nacional durante o primeiro semestre de 2012, sob o título de "Do matriarcado primitivo à sociedade contra 0 estado e além: cartografia da hipótese antropofágica”. Saliento que todo o texto que se segue canibaliza os ensinamentos proferidos pelos citados professores.
} 


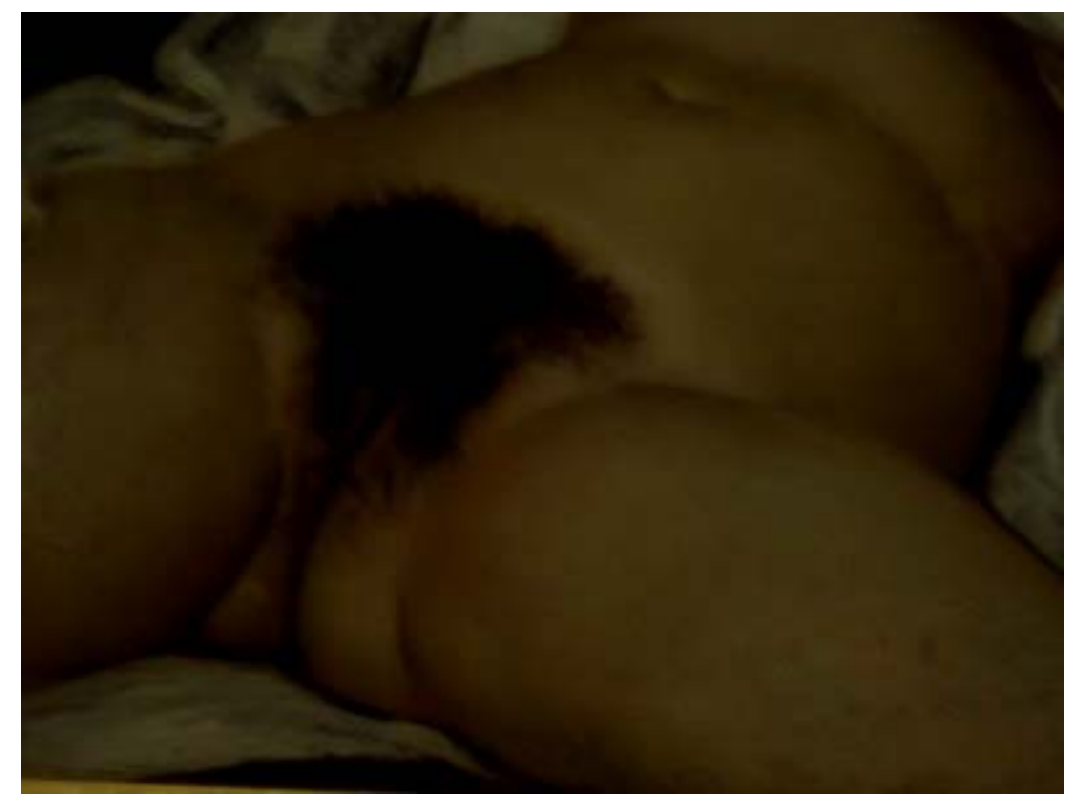

FIG. 1 - Gustave Coubert. A origem do mundo, 1866.

I.

1808. Passados trezentos anos da descoberta do Novo Mundo, a Europa reverberava, de uma forma ou de outra, os desdobramentos do Séculos das Luzes, cujas insígnias exortavam o crescente domínio da cultura sobre a natureza e a universalidade dos valores humanos, como bem queria a Revolução Francesa. Do teocentrismo remanescente da cristianização do Império Romano ao antropocentrismo renascentista, ${ }^{2}$ nota-se a retomada, por este, da herança deixada pela Grécia antiga, obnubilada, em parte, pelo contumaz monopólio do conhecimento pela Igreja Católica. Se, malgrado o arrefecimento da postura proibitiva da Igreja em relação aos escritos precedentes ao seu soberano governo, as luzes da renascença pouco conspurcavam as diretrizes cristãs, na mesma medida em que estas em muitos pontos corroborariam parte do legado grego, por outro lado, o século 19, caso mantemos o foco sobre determinada tradição germânica, mostra-se empenhado em releituras inauditas de ambas tradições. Nesse ano, concomitantemente à partida da Coroa Portuguesa ao Brasil em fuga das tropas de Napoleão, Heinrich von Kleist edita a tragédia Pentesileia, ${ }^{3}$ colocando-se, a exemplo de $O$ terremoto no Chile, tornado público pelo mesmo autor em

${ }^{2}$ Acentua-se, no campo da filosofia, a importância do cogito ergo sum cartesiano, ou, posteriormente, a aufklärung kantiana como propulsores decisivos da visão antropocêntrica do mundo. Vale notar, também, os avanços da matemática e da física, assim como os das tecnologias de produção e navegação.

\footnotetext{
${ }^{3}$ KLEIST. Pentesileia.
} 
1807, em um interessante embate não só com ambas as tradições citadas - no caso daquela, em confronto direto com a tragédia grega e, deste, em embate com a postura cristã, como veremos -, como com aquilo que, correntemente, se entende por civilização.

Sabe-se da interlocução de Kleist com os expoentes do importante Romantismo alemão, quais sejam, Johann Wolfgang von Goethe e Friedrich Schiller; entretanto, nota-se, primeiramente, que o primeiro pouco gozou, naquele tempo, do reconhecimento do qual compartilhavam os demais, assim como seus escritos, em segundo lugar, mal se encaixavam nos moldes daquele movimento, devido, principalmente, à violência que ali figurava. ${ }^{4} \mathrm{O}$ Romantismo, que no combate à universalidade trazida pelos distintivos do Positivismo francês potencializado pela revolução, ora pendia ao nacionalismo, ora levava tal postura a entraves ontológicos mais complexos, como torna-se visível em um certo elogio ao “primitivismo”, ganha, em Kleist - pois, se ali seus escritos não se encaixavam, pondera-se, para todos os efeitos, que por aquele movimento sua obra encontra-se, inevitavelmente, permeada -, fecundas inflexões relativas à força bruta, à animalidade que se recusa abandonar o homem civilizado, aos efeitos dos resíduos primevos da natureza que continuam a subsistir na cultura. Já no primeiro ato (prólogo) de Pentesileia, por exemplo, as amazonas, para o desespero do Rei Ulisses e seus séquitos, sob o comando da personagem cujo nome intitula a peça, invadem Troia como "lobas raivosas sem nem mesmo saber por que”, promovendo, como corolário da referida ação, uma "carnificina”, 5 conforme as palavras do absorto Rei. Todavia, antes de prosseguirmos, vale a indagação: quem são as amazonas, essas furiosas mulheres guerreiras?

Em um encontro com Aquiles, por quem Pentesileia se apaixona - e, apesar da oportunidade, a líder abdica de matá-lo em sua primeira invasão a Troia, citada por nós; como o guerreiro, posteriormente, retribui o gesto de piedade - testemunhando, na ocasião, a reciprocidade do sentimento, ela se põe a responder a seguinte interrogação do filho de Peleu: "Por que atacar os Gregos, se lhe bastava simplesmente a beleza para ter o outro sexo a seus pés?” Entreve-se na pergunta que as amazonas guerreavam para - como nos aclara, posteriormente, o texto - realizar grandes orgias com os prisioneiros de guerra, que se tornavam, ao serem derrotados, espécie de escravos sexuais das virgens que cumpriam, por

\footnotetext{
${ }^{4}$ Agradecemos as orientações do professor Georg Otte sobre os problemas relativos à (não) inserção de Kleist naquilo que hoje se entende como Romantismo alemão.

${ }^{5}$ KLEIST. Pentesileia, p. 1.
} 
sua vez, ordens das suas superiores mães. ${ }^{6}$ Tratava-se, pois, de um matriarcado radical. No entanto, nem sempre fora assim. Segundo Pentesileia, “onde hoje vive o povo das amazonas, vivia outrora, em paz com os deuses, uma tribo dos Citas (...), livre e guerreira”, até que "um dia, um rei etíope apareceu e abateu, primeiro, todos os guerreiros e, depois, todas as crianças e todos os velhos”, permitindo que os vencedores arrancassem as esposas dos túmulos dos seus cônjuges, arrastando-as "para seus leitos desonrados".7 Indignadas, as mulheres se vingam por meio da rainha Tanaís, desposada pelo rei a contragosto, que apunhala este no ensejo comemorativo de suas bodas e, "na mesma noite, toda a tribo criminosa foi acariciada a golpe de punhal e morreu”. ${ }^{8}$ Inaugura-se, após a retaliação, “um Estado sem tutela, um Estado no qual nenhuma voz masculina daria ordens arrogantes", 9 propondo, para tanto, que “todo recém-nascido homem seria (seja) morto”. Por fim, restava o derradeiro entrave para a instauração do governo exclusivamente feminino na Cítia, posto por Tanaís: “como mulheres fracas, atrapalhadas por fartos seios, conseguirão retesar um arco?” Para tanto, por meio de um gesto que replicava sua própria questão, a rainha “decepou, de um só golpe, o seio direito e batizou de amazonas, o que quer dizer 'seios cortados', as mulheres capazes de retesar o arco”. 10

Extirpar um seio é a cláusula para que as mulheres assumam a condição de guerreiras, designada, até então, somente aos homens. Passam, assim, a portar a flecha para que, após uma guerra entravada na selva, tragam os machos para fecundar o ventre das moças. E, de tal sorte, “quando uma nova safra brota em seu ventre, elas celebram a Festa das Mães. Festa triste, porque é quando os homens voltam, carregados de presentes e com grande aparato, para sua terra natal”. ${ }^{11}$ A exigida injunção do contato com o sexo oposto torna, porém, infinda a guerra entre as mulheres e os gregos, uma vez que o sentimento de Pensileia por Aquiles se intensifica, e subjugar o herói da Grécia é a única forma de possuí-lo. A indignação da sacerdotisa das amazonas, assim como das outras comandantes, dirigida à ideia de Pentesileia de realizar uma nova retaliação, mesmo após terem fracassado em uma das batalhas, coloca em questão a sanidade da líder, borrada, por sua vez, pelo contumaz sentimento. Como diz a

6 “Pentesileia (a Aquiles): A vontade de nossas mães decidiu assim e nós nos inclinamos diante dela como você diante da tradição de seus pais” (KLEIST. Pentesileia, p. 38).

\footnotetext{
${ }^{7}$ KLEIST. Pentesileia.

${ }^{8}$ KLEIST. Pentesileia, p. 39.

${ }^{9}$ KLEIST. Pentesileia.

${ }^{10}$ KLEIST. Pentesileia.

${ }^{11}$ KLEIST. Pentesileia, p. 40.
} 
comandante, "no coração das mulheres nascem tantas coisas que não são feitas para a luz do dia”, 12 ainda que elas gerem opróbrio às orgulhosas amazonas.

Ciente das condições para unir-se à Pentesileia, Aquiles convoca, novamente, as guerreiras para o derradeiro confronto, ainda que soubesse do quão debilitada encontrava-se a rainha em consequência da última guerra que ambos travaram entre si, e, por outro lado, da atonia de seu exausto exército. O plano do guerreiro partia da certeza de que Pentesileia jamais o aniquilaria, todavia, torná-lo-ia escravo, caso o vencesse, deixando-o retornar livremente ao seu trono após as orgias e o período de gestação. Posteriormente à Festa das Mães, Aquiles convocaria a rainha ao seu reinado, persuadindo-a para que abandonasse o governo das amazonas. A paixão que acometia Pentesileia fornecia a Aquiles, ou pelo menos assim ele imaginava, a convicção de que seu plano era infalível, fazendo-o ir à guerra destituído de armas ou proteção, como fosse o evento um simples protocolo para execução do seu projeto. Paremos por aqui.

\section{II}

Pouco mais de meio século após a referida tragédia de Kleist, era publicado, em Stuttgart, um dos mais importantes - ainda que tenha permanecido, por algum tempo, sem o devido reconhecimento - estudos do antropólogo e jurista suíço Johann Jakob Bachofen, qual seja, O matriarcado. Em semelhança ao trabalho de Kleist, voltava-se, aqui, novamente os olhos para a mitologia grega, além do direito romano. No entanto, talvez como estratégia metodológica, Bachofen, esse aristocrata da Basileia, discípulo de Friedrich Savigny, pretendia ler o mito como reverberação de um contexto do qual ele emanava, em contraponto a uma leitura exclusivamente imanente praticada até então, para que, assim, pudesse se extrair não apenas aquilo que as narrativas delatavam acerca de um determinado universo - e, nesse sentido, o mito seria história - todavia, e, sobretudo, para que possibilitassem evidenciar o que nelas era censurado, i.e., aquilo que ali encontrava subterfúgio, mostrando-se escondido “em nível cultural reprimido”. ${ }^{13}$ Constatava, pois, que a mitologia grega era subjazida por um embate entre os gêneros, especificamente da vitória do poder pátrio sobre o direito materno, a arcaica estrutura do matriarcado, que em quatro fases se sucedeu: $1^{0}$ teríamos o heterismo prostituição das cortesãs gregas -, espécie de promiscuidade primitiva na qual os homens, pela força, dominavam as mulheres, como o sobressalto do rei da Etiópia, da peça de Kleist,

\footnotetext{
${ }^{12}$ KLEIST. Pentesileia, p. 29.

${ }^{13}$ GARCIA. Introducción, p. 10.
} 
com as moças da Cítia; $2^{\circ}$ as mulheres se rebelaram violentamente, instaurando a civilização amazônica, tal qual a deusa Tanaís vingando-se do soberano etíope e dos seus séquitos, submetendo os homens restantes ao domínio feminino; $3^{\circ}$ forma-se o matriarcado incluindo os homens - e, aqui, teríamos, talvez, uma relação mais estritamente subsequêncial, uma vez que, para Bachofen, o amazonismo seria uma forma degenerada de matriarcado ${ }^{14}$-, todavia, sob a égide da linhagem feminina, a qual obedeciam os nascimentos, ao passo que, na outra mão, instaura-se o matrimônio - exigência feminina para findar o heterismo - e a agricultura - correlata da relação sexual ordenada, segundo Bachofen; $4^{\circ}$ no entanto, para o jurista, este seria instável já que impedia o "desenvolvimento de energia”, 15 dando margem à passagem do direito natural ao civil, à religião apolínea potencializada pela formação do Estado romano, ao triunfo da razão como aspecto excelso da cultura, à cisão e sobrepujamento do tempo mítico pelo tempo histórico, i.e., finalmente, ao patriarcado.

Pouco pertencia o matriarcado - momento este, portanto, "posterior" ao que nos mostra a tragédia de Kleist - a um povo específico, sendo ele, antes, um "estágio cultural”16 que poderia, todavia, permanecer em algumas civilizações como, por exemplo, a dos Lícios, que, segundo os relatos de Heródoto, mantinham a linhagem da prole sob o nome da mãe, tornando nobres os filhos de uma mulher com um escravo e cidadãos comuns a geração dos homens com estrangeiras. ${ }^{17} \mathrm{O}$ parricídio, como demonstra a pesquisa filológica do teórico, era, no citado contexto, um crime contra qualquer indivíduo e não um delito cuja aplicação restringia-se ao pai, uma vez que todos, no matriarcado, são filhos da terra, i.e., "todo ventre da mulher é a imagem da mãe-Terra”. ${ }^{18}$ Destarte, segundo o direito materno, "todos os homens são igualmente livres”, ${ }^{19}$ pertencentes à unidade primeva da natureza, prevalecendo a

${ }^{14}$ Ressaltamos tal ponto, pois, para Bachofen, a história como sucessão linear de grandes feitos é característica própria do patriarcado, podendo, então, as outras fases coexistirem no tempo (subtendendo-se o próprio tempo como coexistência).

${ }^{15}$ GARCIA. Introducción.

${ }^{16}$ BACHOFEN. O matriarcado: una investigación sobre la ginecocracia en el mundo antiguo según su naturaleza religiosa y jurídica, p. 28-29. Tivemos acesso à edição espanhola. Todas as traduções são nossas.

${ }^{17}$ BACHOFEN. O matriarcado: una investigación sobre la ginecocracia en el mundo antiguo según su naturaleza religiosa y jurídica, p. 72.

${ }^{18}$ BACHOFEN. O matriarcado: una investigación sobre la ginecocracia en el mundo antiguo según su naturaleza religiosa y jurídica, p. 37.

${ }^{19}$ BACHOFEN. O matriarcado: una investigación sobre la ginecocracia en el mundo antiguo según su naturaleza religiosa y jurídica, p. 195. 
lei desta em detrimento do nomos indivídual, ${ }^{20}$ haja vista o vilipêndio àquele que teria fecundado o ventre da mulher: não importa quem é o pai, o filho é, sempre, da mãe, da tribo.

De tal sorte, o jurista infere como, por exemplo, no mito grego, ${ }^{21}$ haveria uma polarização entre as duas formas de organização social na qual cada uma agruparia em torno de si uma série de elementos: o lado esquerdo, a noite, a lua, a terra, o corpo, o lado obscuro e mortal da Natureza, e, assim, consequentemente, os defuntos e o luto estariam como características da organização social submetida à linhagem feminina, assim como o sentido destro, o dia, o sol, a água que fecunda a terra (Poseidon), a eternidade da luminosidade espiritual, os vivos e a alegria, respectivamente, seriam próprios do patriarcado. ${ }^{22} \mathrm{O}$ materno telúrico material se oporia ao paterno urânico/apolíneo espiritual; todavia, como denuncia o mito da Lícia, narrado por Plutarco, o lado matriarcal é bífido - como a Lua, que é andrógina - na medida em que Belorofonte, herói da narrativa, vence as amazonas e os homens estrangeiros que destruíam as cidades costeiras da Lícia e, como não fora recompensado com a eternidade da vida pelo feito, pede a Poseidon para salgar a terra, tornando-a infértil - a divindade acaba por inundá-la -, castigando, assim, a matéria física. A personagem, porém, arrepende-se, suplicando ao deus que desfizesse a anátema, considerando o pedido das mulheres. Finalmente, frustrando-se da possibilidade de tornar perene sua vida, o herói permanece num limbo, entre humanos e não humanos, corpo e espírito, tal qual Prometeu. Este “entre-lugar” coaduna-se à Mãe-Terra, geradora de todas as coisas, no qual é incluso, outrossim, a água fecundante do homem (Poseidon). Como diria Bachofen, “a morte é

${ }^{20}$ BACHOFEN. O matriarcado: una investigación sobre la ginecocracia en el mundo antiguo según su naturaleza religiosa y jurídica, p. 47.

${ }^{21}$ ENGELS. A origem da família, da propriedade privada e do Estado, p. 24-25. O principal deles seria a Orestia, de Ésquilo, sobre o qual Engels nos fornece bom resumo, que parafraseamos a seguir. No mito, Clitemnestra, levada por sua paixão por Egisto, mata Agamenon, seu marido, quando este regressava da Guerra de Troia. Entretanto, Orestes, filho dela e Agamenon, vinga o pai, matando a mãe. Assim ele é perseguido pela Erínias, seres demoníacos protetores do direito materno; Apolo e Atenas o protegem, sendo esta a juíza do caso. As Eríneas argumentam que matar o marido não teria importância, pois ela não possuía vínculo de sangue com ele - conforme funciona o matriarcado. O caso é levado ao Areópago - júri grego - e permanece irresoluto, até que Atenas concede o voto de minerva fazendo vencer o patriarcado.

${ }^{22}$ BACHOFEN. O matriarcado: una investigación sobre la ginecocracia en el mundo antiguo según su naturaleza religiosa y jurídica, p. 34.Vale notar que há um rechaço por parte do feminismo em relação aos trabalhos de Bachofen sob a justificativa de "essencializar" a mulher. A diatribe poderia sobrevir ao fato de o próprio jurista, como mostraremos, maldizer o matriarcado, mas não pelo motivo referido, uma vez que a própria noção de essência vincular-se-ia ao patriarcado, enquanto a figura da mulher, como símbolo de uma vida em simbiose com a natureza, estaria conectada à vida subjazida pela morte, ao eterno devir, contrário, por sua vez, à essência do Ser patriarcal. Vale notar este artigo de BAMBERGER. O mito do matriarcado: por que os homens dominam as sociedades primitivas? 
condição prévia da vida, e esta se compõe de novo com aquela; a geração mantém imortalidade no eterno cambio dos pólos (...) o Matriarcado é duplo”, ${ }^{23}$ luz e sombra, basculação entre eterno luto e ubíqua esperança no porvir; portanto e, finalmente, mundo do eterno devir, vencido, entretanto, pelo mundo do eterno Ser. ${ }^{24}$

O aspecto instintivo do governo matriarcal é correlativo ao desejo sensual, à vertigem crescente, tornando Dionísio - um deus asiático, no entanto, filho de Zeus com Semele, masculino que se veste de mulher, duplo, duas vezes nascido e capaz de fazer mágicas -, por exemplo, “um deus das mulheres, a fonte de todas suas esperanças terrenas e sobrenaturais”. 25 Este, contudo, é minorado pelo individualismo, tendo em vista que "a família fundada no patriarcado se isola em um organismo individual”, contrariamente à característica típicogeneral da família matriarcal. ${ }^{26}$ A devoção à natureza abdica à sobrelevação perante ela, assim como a materialidade Dionisíaca à pureza Apolínea. ${ }^{27} \mathrm{E}$, malgrado a confissão de que o período ginecocrático do mundo "é a poesia da história”, ${ }^{28}$ Bachofen evoca sua diatribe ao matriarcado louvando a "duradora garantia da paternidade" petrificada, por sua vez, pela “ideia estatal romana, que proporcionou uma severa forma jurídica” cuja execução estendia-se a "todos os campos da existência”, julgando, por fim, os mistérios dionisíacos e o oriente matriarcal como perigos justamente combatidos. ${ }^{29}$ Não deixa de ser curioso que o aviltamento do ius naturale pelo ius civile, subjazido pela afirmação do direito superior romano cuja potestas, sobre as mulheres e os filhos, afirma o imperium estatal-uniforme, ${ }^{30}$ mostre-se terço ao aristocrata, agradando-o, conquanto este reconheça ser “o pai uma ficção jurídica enquanto

${ }^{23}$ BACHOFEN. O matriarcado: una investigación sobre la ginecocracia en el mundo antiguo según su naturaleza religiosa y jurídica, p. 78.

${ }^{24}$ BACHOFEN. O matriarcado: una investigación sobre la ginecocracia en el mundo antiguo según su naturaleza religiosa y jurídica, p. 77.

${ }^{25}$ BACHOFEN. O matriarcado: una investigación sobre la ginecocracia en el mundo antiguo según su naturaleza religiosa y jurídica, p. 56.

${ }^{26}$ BACHOFEN. O matriarcado: una investigación sobre la ginecocracia en el mundo antiguo según su naturaleza religiosa y jurídica, p. 37.

${ }^{27}$ BACHOFEN. O matriarcado: una investigación sobre la ginecocracia en el mundo antiguo según su naturaleza religiosa y jurídica, p. 34.

${ }^{28}$ BACHOFEN. O matriarcado: una investigación sobre la ginecocracia en el mundo antiguo según su naturaleza religiosa y jurídica, p. 41.

${ }^{29}$ BACHOFEN. O matriarcado: una investigación sobre la ginecocracia en el mundo antiguo según su naturaleza religiosa y jurídica, p. 69.

${ }^{30}$ BACHOFEN. O matriarcado: una investigación sobre la ginecocracia en el mundo antiguo según su naturaleza religiosa y jurídica, p. 107. 
a mãe um fato físico”. ${ }^{31}$ Finalmente, subentende-se, em seu estudo, como um progresso da civilização a conversão da unidade original (a mãe natureza) à multiplicidade, ${ }^{32}$ ainda que “o desenvolvimento do patriarcado leva ao primeiro plano um aspecto completamente distinto da natureza humana”. 33 A Guerra de Troia, na qual as amazonas são derrotadas, é, para Bachofen, uma grande contribuição à vitória do patriarcado; todavia, vale notar a inexistência de qualquer menção à peça de Kleist.

As concatenações do jurista produzem efeitos vastos no pensamento que a procede, particularmente aqueles que se detêm sobre as vissitudes pelas quais a civilização é acometida desde tempos imemoriais. Exatos 10 anos após sua publicação, por exemplo, Friedrich Nietzsche desenvolve a tão hoje propalada polarização entre o dionisíaco e o apolíneo. Ainda que pretira qualquer referência ao jurista, seu colega de docência, hoje é sabido a influência do último sobre "metafísca de artista” do filósofo. Ela pode ser constatada, por exemplo, se observarmos o conceito-chave propulsor da caracterização do estado apolíneo. Trata-se do principium individuationis, retirado de Schopenhauer, cujo efeito confere serenidade ao homem frente à imprevisibilidade, ao aspecto revolto da natureza. Todavia, ao constatar inevitabilidade de exceções a qualquer ordem causal na qual se agrupe os fenômenos, o homem é apoderado pelo horror, levando a falência o princípio de individuação. Para Nietzsche, entretanto, do prejuízo do referido princípio sobrevém, além do espanto, “o êxtase arrebatador”, que irrompe “do que há de mais profundo no homem e na própria natureza”.34 Se a condição apolínea, que nos diz da mais "alta verdade, a perfeição deste mundo, opostas à realidade imperfeitamente inteligível” do cotidiano, encontra sua imagem afim na "natureza reparadora e salutar do sono e do sonho”, a situação dionisíaca, por sua vez, possui sua analogia na embriaguez, que vai atrair "o indivíduo subjetivo para o obrigar a aniquilar-se no total esquecimento de si mesmo”, ${ }^{35} \mathrm{E}$, em tal ensejo, “não é somente a aliança do homem com o homem que fica novamente selada pela magia do encantamento dionisíaco”, no qual “o escravo é um homem livre, porque se quebram todas as barreiras rígidas e hostis que a miséria (...) ou o 'modo insolente' haviam estabelecido entre os homens', todavia, outrossim, “a

${ }^{31}$ BACHOFEN. O matriarcado: una investigación sobre la ginecocracia en el mundo antiguo según su naturaleza religiosa y jurídica.

${ }^{32}$ BACHOFEN. O matriarcado: una investigación sobre la ginecocracia en el mundo antiguo según su naturaleza religiosa y jurídica, p. 106.

${ }^{33}$ BACHOFEN. O matriarcado: una investigación sobre la ginecocracia en el mundo antiguo según su naturaleza religiosa y jurídica, p. 45.

${ }^{34}$ NIETZSCHE. A origem da tragédia, p. 23.

${ }^{35}$ NIETZSCHE. A origem da tragédia, p. 23. 
natureza, alienada, inimiga ou subjugada, celebra sua reconciliação com o filho pródigo, o homem”. ${ }^{36}$ Desse modo, “os animais falam, já a terra produz leite e mel, por que a voz do homem adquiriu uma ressonância de ordem sobrenatural. O homem (...) sente-se Deus (...), deixa de ser artista para se tornar obra de arte”. ${ }^{37}$

Nesse estádio, “os instintos naturais se aproximam e se satisfazem diretamente”; 38 foi preciso que o espírito apolíneo encontrasse ${ }^{39}$ os "bárbaros dionisíacos” - brutalmente diferentes dos "gregos dionisíacos” -, tendo em vista que estes possuíam "licença sexual desenfreada, cujo fluxo exuberante não se detém respeitosos perante a consanguinidade, e transpondo os limites da moral ${ }^{40}$ submerge a leis veneráveis da família”. ${ }^{41}$ Tal "reconciliação" dos polos, como a entende Nietzsche, permite que o "aniquilamento do princípio de individuação" converta-se em "fenômeno artístico", ${ }^{42}$ como realiza a tragédia ática, obra de arte superior provinda do abraço entre beleza medida e o desmedido excesso da natureza, o Uno primordial/verdadeiro Existente com a absoluta Inexistência (a realidade empírica do perpétuo devir no tempo), o individual e o princípio da equidade, Apolo e Dionísio: um verdadeiro milagre da “vontade” helênica, segundo o pensador.

Vale notar que, em momento bastante distinto de sua produção, Nietzsche retoma as origens da moral ao passo que a desconstrói, postulando-a como invenção daquele cuja força os demais se submeteriam. O comumente concebido como "bom”43 não emanaria das próprias coisas ou ações, sendo, nada mais, que um sistema de valores - a própria moral - criado por aqueles superiores dominantes que encontram-se no poder para se bendizerem. A introjeção do sistema moral, ao qual o vencido deve submete-se, dar-se-ia por meios extremante violentos, garantindo sua eficácia e, produzindo, como corolário, o que entende-se por memória. Desde os tempos primevos, portanto, haveria um impetuoso arrolamento entre o

${ }^{36}$ NIETZSCHE. A origem da tragédia.

${ }^{37}$ NIETZSCHE. A origem da tragédia, p. 24.

${ }^{38}$ NIETZSCHE. A origem da tragédia, p. 25.

39 Nietzsche refere-se a um "encontro", todavia, tendo em vista o rechaço aos bárbaros (que praticavam o incesto) proferido pelo filósofo, subtende-se uma espécie de correção ou censura.

${ }^{40}$ NIETZSCHE. A origem da tragédia, grifo nosso.

${ }^{41}$ NIETZSCHE. A origem da tragédia, p. 26.

${ }^{42}$ NIETZSCHE. A origem da tragédia, p. 27.

${ }^{43}$ NIETZSCHE. A genealogia da moral, p. 4. A filologia de Nietzsche comprovaria sua tese na medida em que a palavra bom, etimologicamente, em "todas as línguas deriva de uma mesma transformação de idéias; descobri que, em toda parte, a idéia de 'distinção', de 'nobreza', no sentido de ordem social é a idéia-mãe donde nasce e se desenvolve necessariamente a ideia de 'nobre' no sentido de 'privilegiado quanto à alma'”. 
nobre - vencedor pela força e/ou esperteza - e o plebeu, em débito, por sua vez (por ser mau), com o regimento inventariado pelo superior: ter-se-ia, pois, desde sempre, uma relação entre credor e devedor para a qual é necessária “a pessoa se opor à pessoa e se medir com ela”. ${ }^{44}$ “Compra e venda e os seus corolários psicológicos” são, logo, “anteriores às origens de toda organização social”, e, além disso, o cânon moral da justiça, o começo “de toda (...) boavontade (...) sobre a Terra”, ${ }^{45}$ primeiro passo para a elevação do homem frente aos demais animais: enfim, para o filósofo, a descrita relação é $a$ origem da consciência.

O supramencionado panorama, é preciso ressaltar, possui efeitos mais complexos e profícuos que aparenta: a exigida adequação do escravo ao amo - esta dívida - implica uma censura às atividades daquele, à sua exteriorização, i.e., ao ato de materializar no mundo seus impulsos instintivos uma vez que eles estão pendentes ao julgamento do superior. De tal forma, “os instintos sob a enorme força repressiva, 'volvem para dentro', a isto se chama de 'interiorização do homem'; assim se desenvolve o que mais tarde se há de chamar de “alma””. ${ }^{46} \mathrm{O}$ ato punitivo alçou, destarte, “que todos os instintos do homem selvagem, livre e vagabundo, se voltasse 'contra o homem interior'”, ${ }^{47}$ propondo, por conseguinte, um divórcio violento do homem com seu passado animal. Em tal cisão promovida pela punição, estaria, para Nietzsche, a origem do Estado, que, a partir de uma violência brutal, consegue domesticar o animal humano. O Estado é aquele que, como consequencia do seu remoto poder coercitivo, fixa a lei para, meramente, ordenar, estabelecer, determinar. A caminhada para um Império Universal, que a guerra permite à supracitada instituição, é, curiosamente, caminho também para uma "universalidade do divino e o despotismo aplana sempre o caminho do monoteísmo". ${ }^{48}$ Estes, aliados à ciência, ao Ser e à verdade - os quais são meras

${ }^{44}$ NIETZSCHE. A genealogia da moral, p. 39.

${ }^{45}$ Diz Nietzsche: “O sentimento do dever, da obrigação pessoal, tem origem, segundo vimos, nas mais antigas e mais primitivas relações entre os indivíduos, as relações entre credor e devedor (...) Não há estado social, por mais rudimentar que seja, em que não se observe estas relações. Fixar preços, estimar valores, imaginar equivalência, cambiar, tudo isto preocupa de tal modo o pensamento primitivo do homem que, em certo sentido, foi o pensamento mesmo: aqui aprendeu a exercitar-se a mais antiga espécie de sagacidade; aqui brotou o primeiro germe do orgulho humano, o seu sentimento de superioridade sobre os outros animais. (...) A compra e venda e os seus corolário psicológicos são anteriores à origem de toda organização social e o sentimento que nasceu da troca, do contrato, da dívida, do direito, da obrigação, da compensação, transportou-se logo para os complexos sociais mais primitivos e mais grosseiros (nas suas relações com outras agrupações idênticas), ao mesmo tempo que o hábito de comparar uma força com a outra força, de as medir e calcular. (...) Tudo tem seu preço, tudo pode ser pago...” (NIETZSCHE. A origem da tragédia).

${ }^{46}$ NIETZSCHE. A genealogia da moral, p. 51.

${ }^{47}$ NIETZSCHE. A genealogia da moral.

${ }^{48}$ NIETZSCHE A genealogia da moral, p. 57. 
projeções da moral - devem preterir todo desejo, paixão, erro: advindo sotoposto, a partir de então, "todo o estado para além do bem e do mal”. 49

\section{III}

“Qual a origem do Estado?” era, concomitantemente ao ensejo filosófico de Nietzsche, a pergunta que Friedrich Engels ${ }^{50}$ se colocava, vinte anos depois dos trabalhos de Bachofen, a quem atribui condigna menção e, no entanto, afasta-se ao considerar que a passagem do matriarcado ao patriarcado devia-se a condições materiais, ao contrário das causalidades religiosas/mitológicas, ressaltadas pelo suíço. Ainda que julgasse como "misticismo" a metodologia do jurista em ler o mito como história, Engels procede com desvelo em sua avaliação do legado de Bachofen e, além disso, o reafirma ao salientar que a passagem do heterismo à monogamia devia-se exclusivamente às mulheres, que, para tanto, optam, em vista de findar a baderna sexual dos homens, pelo casamento em grupos, i.e.: as tribos dividiam-se em alianças consanguíneas de linhagem feminina, dentro das quais proibia-se o matrimônio. ${ }^{51}$ Trata-se das gens, que eram, então, exógamas. L. Agassiz, por exemplo, no contato com índios em sua viagem ao Brasil, ${ }^{52}$ constatava, além disso, que aos estrangeiros capturados em guerra, por exemplo, eram oferecidas as mulheres da tribo, bem como se dava entre os já citados Lícios.

A vitória do patriarcado, então, pode ser atribuída a uma específica inferência de Bachofen, qual seja, de que ele impedia “desenvolvimento de energia”. O ponto de Engels é, como se podia esperar, basicamente material: com o incremento dos meios de produção, e, consequentemente, acúmulo de riqueza - por sua vez, bastante fortalecido pela pecuária, possível após a domesticação dos animais -, os homens, cuja função era trazer alimentos para casa, acabam se enriquecendo e vendo a necessidade de aglomerar e transmitir seus valiosos bens. Contudo, no sistema de linhagem feminina isto seria impossível, pois "pela morte do proprietário de rebanhos, esses passavam (...) aos seus irmãos e irmãs, e aos filhos destes ou aos descendentes das irmãs de sua mãe; quanto aos seus próprios filhos, viam-se eles

\footnotetext{
${ }^{49}$ NIETZSCHE. A genealogia da moral, p. 92.
}

${ }^{50} \mathrm{O}$ estudioso toma, principalmente, trabalhos inacabados de Marx sobre "A sociedade antiga", do antropólogo Lewis H. Morgan.

${ }^{51}$ ENGELS. A origem da família, da propriedade privada e do Estado, p. 32.

${ }^{52}$ Agassiz citado por ENGELS. A origem da família, da propriedade privada e do Estado, p. 71. Trata-se da obra A journey in Brazil. Boston, 1886. 
deserdados”. ${ }^{53}$ De tal sorte, só poderia haver farto crescimento de excedente caso o direito que estabelecia a herança à linhagem feminina e sua gens sucumbisse. A abolição do direito materno, por fim, “a mais profunda revolução que a humanidade conheceu”, ${ }^{54}$ permitiu não só a herança masculina, que, por sua vez, libera o enriquecimento, como, também, concedeu ao homem a "direção da casa”, convertendo a mulher em "servidora, em escrava da luxúria do homem, em instrumento de procriação". ${ }^{55}$ Se esta passa a ser propriedade masculina, o estrangeiro ou prisioneiro de guerra, com os quais as mulheres já não poderiam copular, transformam-se escravos, com vistas proporcionar o desenvolvimento da produção. Eis, então, a família civilizada: “Flamulus quer dizer escravo doméstico e família é o conjunto de escravos pertencentes a um mesmo homem. Nos tempos de Gaio, a família 'id est patrimonium'(isto é, herança)”. ${ }^{56}$

A monogamia, prerrogativa dos homens - já que o matrimônio feminino não era exclusivamente monogâmico - não se baseia em condições naturais, todavia, econômicas. A propriedade privada triunfa sobre a primitiva. O antigo heterismo transforma-se em pura prostituição; o governo do lar torna-se serviço privado, quando antes era social. O Estado, finalmente, seria um mero corolário do patriarcado, tendo em vista que faz nada além de assegurar a propriedade privada. Portanto, segundo Engels, as sociedades primitivas "não teriam Estado”. 57

O historiador sabia, entretanto, de um antigo costume dos povos primitivos, que, ao seu ver, teria sobrevivido somente enquanto sorte de "rito religioso, ou como ato mágico (Zaubermittel), o que dá no mesmo": ${ }^{58}$ trata-se da antropofagia. Essa tertúlia, devido aos amplos sentidos que possuía nas tribos indígenas, é um encalço distinto para investigar outras circunstâncias propiciadoras da passagem do matriarcado ao patriarcado. Para além das condições materiais - ou, pelo menos, como as concebia Engels -, os trabalhos do psicanalista Sigmund Freud - que confere apenas uma citação à Bachofen -, que ia à antropologia buscar fortuna para sua crítica da psique (tornando-se, para tanto, social), atentavam às acepções conspícuas que trazia o rito canibal. Antes de abordá-las, porém, vale notar que o núcleo da “família” primitiva que Engels investigava sob o conceito de gens era consubstancial aos

\footnotetext{
${ }^{53}$ ENGELS. A origem da família, da propriedade privada e do Estado, p. 74.

${ }^{54}$ ENGELS. A origem da família, da propriedade privada e do Estado, p. 77.

${ }^{55}$ ENGELS. A origem da família, da propriedade privada e do Estado, p. 77.

${ }^{56}$ ENGELS. A origem da família, da propriedade privada e do Estado, p. 78.

${ }^{57}$ ENGELS. A origem da família, da propriedade privada e do Estado, p. 124.

${ }^{58}$ ENGELS. A origem da família, da propriedade privada e do Estado, p. 42.
} 
toténs apresentados pelo psicanalista: assim como aquelas, estes aventavam sobre alianças consanguíneas exogâmicas obedientes à linhagem feminina reunidas, entretanto, sob a insígnia de um animal ou planta, espécie de antepassado comum cuja devoração (da carne, no caso dos animais) era interdita, configurando-se, por sua vez, como tabu. O tabu dos melanésios, por exemplo, seria correlato ao termo sacer empregado pelos romanos, cujo sentido manifesta-se, em ambos os casos, ambivalente: por um lado "sagrado" e por outro “proibido, impuro. O inverso do 'tabu’ em polinésio é 'no’, que significa comum, geralmente acessível”. ${ }^{59}$ Aquele é inabordável enquanto este pode ser tocado, trazido ao usufruto comum. O tabu seria, finalmente, em acordo com Freud, o mais "antigo dos deuses e remonta a um período anterior à existência de qualquer espécie de religião”. 60

A querela instaura-se à medida que a proibição - o que quer dizer que o tabu é uma imposição de um poder - mostra-se incapaz de obnubilar o instinto, levando-o, exclusivamente, ao inconsciente, reprimindo-o. Por outro lado, entreve-se nesta latência de um desejo subjacente à proibição que, seja o tempo que leve, a violação do tabu acontecerá e, por isto ela era, inclusive, prevista: aquele que o violasse, para tanto, converter-se-ia em tabu, i.e., em vida sacra. De maneira concomitante, surge a consciência, à medida que se instaura, pela censura externa, a autocensura do sujeito, a culpa, ${ }^{61}$ espécie de dívida.

O totem, que serve, também, de nomenclatura, i.e., de distinção entre os seres, auxiliando a vida cotidiana - e daí sua proveniência, conforme Freud -, fornece explicação à dúvida acerca do processo de reprodução da espécie, vá dizer, sobre a origem da concepção dos seres humanos, haja vista que o animal é um ancestral. A proibição em comê-lo adquire, portanto, sentido adjacente: devorar o totem "equivaleria a comer a si próprio”. 62 Todavia, isso era realizado nos festins sacrificatórios que, para cometer o crime, reunia todos os integrantes da tribo sem exceção, uma vez que a "comunidade, o deus e o animal sacrificado eram do mesmo sangue e membros de um só clã”. ${ }^{63}$ O grupo deveria estar coeso para tal derramamento de sangue, no qual se praticava, com o animal totêmico, a omofagia, ao passo que se vestiam e se comportavam imitando-o, num gesto de incorporação, conforme o psicanalista. Após a deglutição, instaurava-se o luto pelo ato, procedido, todavia, por contumaz regojizo festivo. O prazer, no ensejo, tornava-se potencializado pelo aspecto

${ }^{59}$ FREUD. Totem e tabu, p. 32. A edição que tivemos acesso para este artigo é problemática.

${ }^{60}$ FREUD. Totem e tabu.

${ }^{61}$ FREUD. Totem e tabu, p. 82.

${ }^{62}$ FREUD. Totem e tabu, p. 138.

${ }^{63}$ FREUD. Totem e tabu, p. 158. 
interdito da devoração, ao passo que a culpa adviria inócua porque o delito era empreendido em conjunto.

Por aclarar a ascendência da tribo de linhagem feminina, depreende-se que o totem seria, para Freud, aquele que, em tempos imemoriais, teria fecundado a mulher, ou seja, o pai. Tratar-se-ia, entretanto, daquele gerador primevo que havia executado os irmãos e demais machos dominando, pela força, as fêmeas, tal qual advém no heterismo, não citado por Freud. Para impedir a citada catástrofe para a vida social, os irmãos e filhos teriam achado por bem assassinar o pai, libertando as mulheres e as relações sexuais com elas. O animal totêmico, logo, seria nada mais que a simbolização do sacrifício deste soberano como impedimento da guerra infinda, uma vez que os filhos tentariam repetir o mesmo ato do poder pátrio para adquirir sua privilegiada posição. A refeição totêmica, desse modo, não representa somente o crime comum da morte do pai, permitindo a convivência social e, por conseguinte, o matriarcado, no entanto, ao mesmo tempo, a oportunidade de realizar o desejo subjacente de ser este pai autorizado, por sua vez, pelo ato da antropofagia, correlato de uma encarnação, incorporação. Isto quer dizer que o devorador, ao elevar-se na categoria de pai durante a deglutição, experimenta, momentaneamente, sua condição, i.e, torna-se a divindade deglutida, torna-se deus.

Segundo Freud, a antropomorfização dos animais totêmicos, consequente do desenvolvimento da agricultura e domesticação destinada aos animais “reais” - para os quais não se dedica mais uma relação simbiótica, mas de distanciamento e preterimento, seguindo o mesmo para a natureza como um todo - torna possível a volta do pai outrora vilipendiado, vá dizer, libera o encerramento do totemismo. ${ }^{64}$ Se a tragédia grega repetia o pai morto, Cristo teria redimido a culpa pela morte do pai, sendo a "restituição do patriarcado” nada mais que o retorno do pai primevo. Dessa forma, como na mitologia judaíco-cristã, especifica-se o crime, isto é, quem teria executado o pai, convertendo o assassinato inculpe na culpa comum de todos: finalmente, numa dívida eterna. Surge, daí, um pai imaterial, espiritual, porém, único, específico. Por isso, o sangue e o corpo de Cristo só pode ser deglutido por meio da hóstia e do vinho, ou seja, vale-se da mediação em detrimento da antropofagia i-mediata. Forma-se a compulsão em venerar um Deus-Pai que não se pode ver, inalcançável, permitindo “o triunfo da intelectualidade sobre a sensualidade", ${ }^{65}$ pois esta é demonstrada pela evidência dos sentidos e aquela é uma hipótese. Por fim, no patriarcado - radicalizado pelo monoteísmo - a

\footnotetext{
${ }^{64}$ FREUD. Totem e tabu.

${ }^{65}$ FREUD. Moisés e o monoteísmo, p. 128.
} 
civilização só pode ser a "proteção do homem frente à (Mãe) natureza", 66 i.e., aos seus próprios instintos, ao seu corpo, às suas sensações, à sensualidade, aos animais selvagens, ao imprevisível, ao devir, à morte.

\section{IV}

É hora de volvermos, pois, à Pentesileia. A heroína encontrava-se condenada pelas companheiras não apenas devido a um sentimento que arrefecia sua razão, como pelo fato da sua paixão - este pathos - borrar uma outra regra do amazonismo, qual seja: o impedimento da escolha do parceiro, uma vez que este deveria ser aquele que, em acordo com a imprevisibilidade da guerra, rendia-se aos pés das guerreiras. Após a luta derradeira entre as amazonas e Aquiles, de onde paramos, no primeiro fragmento deste texto, Astéria passava se referir à líder como "aquela que não tem mais nome para nós”. ${ }^{67}$ No ensejo, Aquiles, desarmado, é surpreendido - neste, para ele, falso embate - ao ver Pentesileia avançar furiosa com seus cães, optando, por conseguinte, por fugir da raivosa amazona. A heroína o alcança e, como conta Astéria, “ele (Aquiles) desmorona”, gerando o berro da líder:

“Cães, peguem-no!” Precipitando-se sobre ele com toda a matilha, ela não passa de uma cadela no meio de cães que aferram seu peito, seu pescoço (...) ela arranca a couraça que ainda o cobre e crava seus dentes em seu alvo peito, competindo em ferocidade com os cães. ${ }^{68}$

No entanto, as amazonas, ao resgatar Pentesileia do embate, notam que a líder pouco se recordava do que havia se passado, resolvendo esconder, aos olhos da raivosa comandante, o cadáver de Aquiles. No entanto, Pentesileia desejava saber quem seria sua "ímpia rival” que, não apenas "matou esse corpo cheio de vida, mas quem, pela segunda vez, matou o morto”. ${ }^{69}$ A rainha referia-se ao desfiguramento do cadáver do futuro amante que, absorta, testemunhava, compreendendo o estilhaçamento do defunto enquanto "segunda morte". Porém, a comandante percebe o que teria acontecido, apesar de sua memória mostrar-se transversa em relação ao ocorrido:

Eu o despedacei, não foi? Teria ele morrido de meus beijos? (...) Então foi um erro! Beijar, despedaçar, isso rima... Quem ama de todo coração pode muito bem confundir uma coisa com a outra. (ajoelha-se diante do corpo de

\footnotetext{
${ }^{66}$ FREUD. O mal-estar na civilização, p. 49.

${ }^{67}$ KLEIST. Pentesileia, p. 53.

${ }^{68}$ KLEIST. Pentesileia, p. 53.

${ }^{69}$ KLEIST. Pentesileia.
} 
Aquiles). E você, você me perdoa, não é? Ártemis é testemunha: se me expressei de modo tão errado, foi porque não era dona de meus lábios. Mas agora vou lhe dizer mais claramente o que pensava naquele momento (ela o beija). Era só isso. É verdade que mais de uma mulher se pendura ao pescoço de seu amado e lhe diz: "Eu o amo tanto que o comeria." Mas bastam estas palavras, para elas sentirem náusea. Eu, eu não fiz isso, meu amado. Quando me pendurei a seu pescoço foi para cumprir a promessa, palavra por palavra. Não estava tão louca quanto parece. ${ }^{70}$

Ao designá-la de monstro, a sacerdotisa ordena prenderem-na. A líder, no entanto, diz estar rompendo, naquele momento, com “a lei das amazonas” e seguindo “este jovem guerreiro na morte", ${ }^{71}$ concedendo às (não mais) seguidoras as últimas palavras: "Desço ao fundo do peito como ao fundo da terra e de lá extraio um sentimento destruidor, frio como metal.” Esse sentimento, no entanto, será, nas palavras da líder, “purificado” com o “fogo da desgraça”, mergulhando, duro como um aço, "no veneno corrosivo do arrependimento". ${ }^{72}$ Pentesileia morre de tristeza.

A culpa da rainha instaura-se à medida que as colegas a incriminam, assim como sua tomada de consciência perante o pavoroso ocorrido. A consciência, contudo, tornava-se impossível no momento irascível da devoração do objeto amoroso. Isto nos faz pensar, como já notou uma contemporânea antropologia, ${ }^{73}$ que a antropofagia não se compraz, exatamente, a uma incorporação, como quer a comunhão cristã por meio da hóstia, todavia, precisamente, no contrário: ao invés de um lugar de chegada, da soma de um outro ao eu, ela diz do avesso, i.e., de um ato de saída, de uma ausência do eu de si subjazida pelo encalço do outro: finalmente, do fim do "princípio de individuação” que Nietzsche resgatava de Schopenhauer. No enunciado “eu o amo tanto que o comeria”, percebe-se como a incontrolável paixão da

\footnotetext{
${ }^{70}$ KLEIST. Pentesileia, p. 58

${ }^{71}$ KLEIST. Pentesileia, p. 58.

${ }^{72}$ KLEIST. Pentesileia, p. 59.

${ }^{73}$ VIVEIROS DE CASTRO. O mármore e a murta, p. 220-221. Vale notar a seguinte passagem do antropólogo Eduardo Viveiros de Castro, que diz: “A religião tupinambá, radicada no complexo do exocanibalismo guerreiro, projetava uma forma onde o sociusconstituía-se na relação ao outro, onde a incorporação do outro dependia de um sair de si - o exterior estava em processo incessante de interiorização, e o interior não era mais que movimento para fora. Essa topologia não conhecia totalidade, não supunha nenhuma mônada ou bolha identitária a investir obsessivamente em suas fronteiras e usar o exterior como espelho diacrítico de uma coincidência consigo mesmo. A sociedade era ali, literalmente, 'um limite inferior da predação' (Levi-Strauss), o resíduo indigerível; o que a movia é a relação ao fora. O outro não era um espelho, mas um destino. (...) a filosofia tupinambá afirmava uma incompletude ontológica essencial: incompletude da socialidade e, em geral, da humanidade. Tratava-se, em suma, de uma ordem onde o interior e a identidade estavam hierarquicamente subordinados à exterioridade e à diferença, onde o devir e a relação prevaleciam sobre o ser e a substância”. Porém, salientamos que Freud, apesar de se referir à antropofagia como incorporação, avulta o seu praticante torna-se o pai, o deus, isto é, sai de si.
} 
amazona pretendia, por meio da deglutição, trazer o amado para dentro de si. Entretanto, antes da referida assunção, fica evidente que ao passo que o sentimento da rainha se intensifica ela, progressivamente, abandona sua identidade, seus princípios, sua comunidade e a suas leis, e, por fim, sua consciência e seu juízo no intuito de sê-lo, de converter-se no amado. Trata-se, então, simultaneamente, de uma exteriorização do interior - a saída de si devido ao fim do princípio de individuação - e a interiorização do exterior - o estrangeiro no estômago. De tal sorte, não só a comunidade torna-se cindida - pois sua rainha desrespeita os valores desta, transgride os interditos - como se tem uma abertura ontológica: Pentesileia torna-se estrangeira a si mesma, cuja comprovação temos em sua fala “eu não fiz isso, amado”, imediatamente após realizar uma confissão em sentido oposto. Submissão e sobrepujamento, propriedade e exterioridade, sujeito (o eu, Pentesileia) e objeto (o outro, Aquiles), tornam-se indiscerníveis.

Atenta-se, pois, que havia nos regimentos impostos pelas guerreiras no contato com os homens a precaução de impedir que eles pudessem voltar a dar “ordens arrogantes”. Apaixonar-se por um guerreiro específico seria um desses perigos, e não é fortuito que o plano de Aquiles caminhasse nesse sentido, ao imaginar que a paixão de Pentesileia, no fim, fá-la-ia curvar-se diante de seu trono patriarcal. Então, o gesto da rainha, como nos mostra o texto, ao passo que abre a comunidade ao outro, quebrando a rigidez de sua identidade - na qual a paixão, a escolha do parceiro, as guerras infindas e o matrimônio eram interditos propõe que a possível potestas deste outro advinha, desde sempre, inócua. Seria um passo para que, por um lado, tal “abertura ontológica”, que torna a dicotomia nacional/estrangeiro difusa, "universalizasse” a comunidade das amazonas e, por outro, o impedimento, à maneira freudiana, da imposição, pela força, de um poder, assim como a possibilidade deste torna-se transcendental. Seria, finalmente, um passo do amazonismo em direção ao matriarcado, a um estado dionisíaco, caso o seu crime não fosse individual, o que gera, para a líder, além da culpa - da mais dolorosa consciência autocensora - uma diferida condição sacra.

Antes, porém, vale atentar que Engels, ao inferir que entre os indígenas o Estado era ausente, fica claro, todavia, que a tese de Nietzsche relativa à moral torna-se impertinente, uma vez que o princípio da dívida (e da moral do superior) teria sido, em algum momento, imposto. Seria esse período anterior, ainda que de maneira oblíqua, àquele que o próprio filósofo, em sua metafísica de artista, enunciada quando jovem, propunha por meio do estado dionisíaco, no qual, vale repetir, encontra-se ausência de culpa e de hierarquia, além do excesso em correlação a tal característica da natureza e, por fim, uma vida em simbiose com esta. Portanto, neste, assim como entre os selvagens, inexistiria a dívida, a falta para com 
algo, a necessidade de equiparação. Se, para Nietzsche, tal panorama se estabelece somente enquanto privilégio de um gênero artístico - e não forma de vida, vez que desde o início dos tempos a dívida reina -, vale atentar que, para Engels, ele teria existido apenas como momento incipiente em um processo acumulativo e progressivo, i.e., histórico, no qual fora devidamente sobrepujado. Tal estádio cultural, entretanto, pode ser observado, posteriormente e com mais cuidado, por um antropólogo citado por Freud em Totem e tabu: trata-se de Marcel Mauss, que constatava que os indígenas consumiam, nas festas, o excedente da produção, i.e., jogavam-no fora. ${ }^{74} \mathrm{E}$, uma vez que o excesso é despejado, fica evidente que o impedimento de “desenvolvimento de energia”, que Bachofen deflagrava no matriarcado e Engels julgava como a causa da derrocada deste - já que os homens, por meio da pecuária, teriam conseguido desenvolvê-la - era proposital. Talvez porque com ele impedia-se, concomitantemente, a formação do patriarcado e, consequentemente, do Estado, a partir do impedimento da constituição de grandes fortunas, i.e., de classes.

A transformação do tabu em totem, descrita por Freud, estaria, portanto, ao lado do despejo voluntário como sorte de dispositivos que impedem a instauração do soberano, ${ }^{75}$ assim como a privatização do divino, como era o deus de Moisés, onisciente e onipotente, entretanto, exclusivo do seu povo (ou as monarquias europeias, cujo soberano era de escolha divina). A deglutição comum da carne traz o deus ao corpo, assim como diviniza os corpos profanos, não havendo, pois, necessidade de consciência em relação ao feito, i.e., não há culpa, pois não há sistema moral exterior que a internalize nos outros, uma vez que o sistema exterior encontra-se internalizado. Nesse momento, a última declaração de Pentesileia, na qual a personagem dizia que traria um sentimento destruidor, "frio como um metal”, após sua ida à terra, para que este fosse purificado no "veneno corrosivo" do arrependimento, torna-se bastante interessante.

Ser purificada pela compunção é possível pela relação de autocensura que a líder estabelece consigo devido ao julgamento externo do solitário delito. A partir de então, tem-se duas constatações: da dupla morte de Aquiles e, como diria Ártemis, a anomia que Pentesileia passava a portar com a prática do crime. Tanto Aquiles quanto Pentesileia tornavam-se, então, uma vida sacra, entretanto, no âmbito do poder soberano, como o governo das amazonas (a sacerdotisa, por exemplo) e suas leis morais. Essa vida, de acordo com o sentido do sacer que

\footnotetext{
${ }^{74}$ MAUSS. Ensaio sobre a dádiva. O prejuízo voluntário do excedente nas festas atende pelo nome de potlach.

${ }^{75}$ Em sentido próximo a este que Pierre Clastres chamou as sociedades indígenas de sociedades contra o Estado. Ver CLASTRES. A sociedade contra o Estado.
} 
propõe Giorgio Agamben ${ }^{76}$ - que destina poucas referências à Freud -, caracteriza-se por uma dupla exclusão: primeira, do mundo profano, posteriormente, do sagrado. Por isso, trata-se de uma vida matável, porém, insacrificável, o que quer dizer: pode-se assassiná-la sem que se produza memória sobre o feito, em sentido contrário às tertúlias dos melanésios descritas por Freud, que realizavam o luto pela morte do totem. O ato de Pentesileia, como individual, torna dupla a morte do amado, assim como seu (da líder) corpo é destituído de nomeação, função própria dos totens. A morte, portanto, é dupla, tal qual o homo sacer agambeniano. Seria, como já ressaltado, o contrário de Dionísio, ${ }^{77}$ que é não apenas o estrangeiro na pólis como aquele que nasce por duas vezes. Ou seja, não fosse a individualização do crime de Pentesileia, tratar-se-ia de uma autêntica “ida à Terra”, inculpe, na qual os homens tornar-seiam filhos desta.

Kleist, em $O$ terremoto no Chile, ${ }^{78}$ narra o momento no qual, após o imenso abalo terrestre que a tudo destruíra, dois jovens são libertos na cidade em ruínas para viverem o amor outrora proibido pelo pai da moça, tendo ela sido condenada à morte. Na cena, o casal testemunhava "homens de todas as classes deitados em promiscuidade”, príncipes ao lado de mendigos, como se "tudo que a eles tinha sido tomado, os tivesse fundido em uma única família”. Sentia-se, então, o “divino espírito de sacrifício, de ilimitado desprendimento pela vida, como se ela, à semelhança de bens sem valor, pudesse ser encontrada novamente (...)”. 79 A civilização, com sua postura inversa à descrita, parece condenar-se a repetir a violência dos encerramentos dos textos de Kleist, como temos nas condições da morte de Pentesileia e Aquiles, ou nos fiéis católicos e padres que, ao encontrarem o referido casal na Igreja, restituem a momentaneamente esquecida moral e assassinam ambos com as próprias mãos. Não seria diferente o que fizera a Coroa Portuguesa - estes escolhidos por deus - e os civilizados ao encontrarem, naquele ano, os “selvagens” no Brasil. É o que repetimos ao

\footnotetext{
${ }^{76}$ AGAMBEN. Homo sacer. O poder soberano e a vida nua.

${ }^{77}$ Vale atentar ao texto As bacantes, de Eurípedes.

${ }^{78}$ KLEIST. O terremoto no Chile, 1974. Notamos que, não só esse conto possui interessante relação com o controle do corpo da mulher, como a temática perpassa as obras de Kleist. Vale notar $A$ marquesa de $O \ldots$... que se torna grávida misteriosamente (contrariamente à Virgem Maria, inseminada por um espírito), $O$ órfão, que narra um garoto órfão que tenta se relacionar com a mãe adotiva, Noivado em São Domingo, em que uma menina se apaixona por um estrangeiro na parte francesa do Haiti após a revolta contra os brancos, apesar da proibição do patriarca.

${ }^{79}$ KLEIST. O terremoto no Chile, p. 189.
} 
ignorar que somos parte do mundo, e não o contrário. ${ }^{80}$ Portanto, o que Kleist, naquele tempo, parecia nos avisar, poderia resumir-se em um contemporâneo enunciado do antropólogo Eduardo Viveiros de Castro: "somos natureza, ou não seremos."

\begin{abstract}
This essay aims at an analysis of the tragedy Penthesilea, by Heinrich von Kleist, based on the theories proposed by Johan Jakob Bachofen and by other writers in the German tradition, especially Nietzsche, Engels and Freud. The text focuses mainly on the supposed separation between man and nature/animals.
\end{abstract}

KEYWORDS

Penthesilea, Kleist, Bachofen, matriarchy

\title{
REFERÊNCIAS
}

AGAMBEN, Giorgio. Homo sacer. O poder soberano e a vida nua I. 2. ed. Trad. Henrique Burigo. Belo Horizonte: Ed. UFMG, 2010.

BACHOFEN, Johann Jakob. El matriarcado. Una investigación sobre la ginecocracia en el mundo antiguo según su naturaleza religiosa y jurídica. Introducción e traducción de María del Mar Llinares García. Ediciones Aka: Madrid, 2008.

BAMBERGER, Joan. O mito do matriarcado: por que os homens dominam as sociedades primitivas? In: ROSALDO, Michelle Zimbalist; LAMPHERE, Louise (Org.). A mulher, a cultura e a sociedade. Trad. Cila Ankier e Rachel Gorenstein. Rio de Janeiro: Paz e Terra, 1979.

CLASTRES, Pierre. A sociedade contra o Estado. Trad. Theo Santiago. São Paulo: Cosac Naify, 2003.

ENGELS. Friedrich. A origem da família, da propriedade privada e do Estado. Trad. Leandro Konder. São Paulo: Expressão Popular, 2010.

ÉSQUILO. Oresteia. Trad. Manuel de Oliveira Pulquério. Lisboa: Edições 70, 1991.

FREUD, Sigmund. Moisés e o monoteísmo. In: Obras psicológicas completas. Trad. do alemão e inglês Jayme Salomão. Rio de Janeiro: Imago, 1996. v. XXIII.

FREUD, Sigmund. O mal-estar na civilização. In: . Obras completas. Trad. Paulo César de Souza. São Paulo: Companhia das letras, 2010. v. 18.

\footnotetext{
${ }^{80}$ VIVEIROS DE CASTRO. Desenvolvimento econômico e reenvolvimento cosmopolítico.

${ }^{81}$ VIVEIROS DE CASTRO. Desenvolvimento econômico e reenvolvimento cosmopolítico.
} 
FREUD, Sigmund O futuro de uma ilusão. Trad. Renato Zwick. Porto Alegre: L\&PM, 2011.

FREUD, Sigmund Totem e tabu. Trad. Órizon Carneiro Muniz. Rio de Janeiro: Imago, 1975.

GARCÍA, María del Mar Llinares. Introducción. In: BACHOFEN, Johann Jakob. El matriarcado. Una investigación sobre la ginecocracia en el mundo antiguo según su naturaleza religiosa y jurídica. Introducción e traducción de María del Mar Llinares García. Ediciones Aka: Madrid, 2008.

KLEIST, Heinrich Von. A marquesa d'O... e outras histórias. Trad. Cláudia Cavalcanti. Rio de Janeiro: Imago, 1992.

KLEIST, Heinrich Von. Novelas. Rio de Janeiro: Editora Três, 1974.

KLEIST, Heinrich Von. Pentesileia. Trad. Jean Robert Weisshaupt e Roberto Machado. Disponível em: <http://www.pucsp.br/nucleodesubjetividade/Textos/pentesileia_kleist.pdf>. Acesso em: 9 jul 2012.

MAUSS, Marcel. Ensaio sobre a dádiva. In: . Sociologia e antropologia. Trad. Paulo Neves. São Paulo: Cosac Naify, 2003.

NIETZSCHE, Friedrich. A genealogia da moral. Trad. Joaquim José de Faria. São Paulo: Centauro, 2002.

NIETZSCHE, Friedrich. A origem da tragédia. 13. ed. Trad. Joaquim José de Faria. São Paulo: Centauro, 2004.

VIVEIROS DE CASTRO, Eduardo. A inconstância da alma selvagem - e outros ensaios de antropologia. São Paulo: Cosac Naify, 2002.

VIVEIROS DE CASTRO, Eduardo. Desenvolvimento econômico e reenvolvimento cosmopolítico: da necessidade extensiva à suficiência intensiva. Disponível em: <http://culturaebarbarie.org/sopro/outros/suficiencia.html>. Acesso em: 17 jul. 2012. 